\title{
Apigenin inhibits pancreatic cancer cell proliferation through G2/M
} cell cycle arrest

\author{
Michael B Ujiki ${ }^{1}$, Xian-Zhong Ding ${ }^{1}$, M Reza Salabat ${ }^{1}$, David J Bentrem ${ }^{1}$, \\ Laleh Golkar ${ }^{1}$, Ben Milam ${ }^{1}$, Mark S Talamonti ${ }^{1}$, Richard H Bell Jr${ }^{1}$, \\ Takeshi Iwamura $^{2}$ and Thomas E Adrian*1,3
}

Address: ${ }^{1}$ Department of Surgery and Robert H. Lurie Comprehensive Cancer Center, Feinberg School of Medicine, Northwestern University, Chicago, Illinois, USA, ${ }^{2}$ Department of Surgery, Miyazaki University School of Medicine, Miyazaki, Japan and ${ }^{3}$ Department of Physiology, United Arab Emirates University, Al Ain, UAE

Email: Michael B Ujiki - mujiki@northwestern.edu; Xian-Zhong Ding - xding@northwestern.edu; M Reza Salabat - msalabat@northwestern.edu; David J Bentrem - dbentrem@nmff.org; Laleh Golkar - lgolkar@ hotmail.com; Ben Milam - bm6v@virginia.edu; Mark S Talamonti - mtalamonti@nmff.org; Richard H Bell - rhbell@nmh.org; Takeshi Iwamura - iwamurat@post.miyazaki-med.ac.jp; Thomas E Adrian* - tadrian@uaeu.ac.ae

* Corresponding author

Published: 29 December 2006

Molecular Cancer 2006, 5:76 doi:10.1 186/1476-4598-5-76
Received: II March 2005

Accepted: 29 December 2006

This article is available from: http://www.molecular-cancer.com/content/5/I/76

(c) 2006 Ujiki et al; licensee BioMed Central Ltd.

This is an Open Access article distributed under the terms of the Creative Commons Attribution License (http://creativecommons.org/licenses/by/2.0), which permits unrestricted use, distribution, and reproduction in any medium, provided the original work is properly cited.

\begin{abstract}
Background: Many chemotherapeutic agents have been used to treat pancreatic cancer without success. Apigenin, a naturally occurring flavonoid, has been shown to inhibit growth in some cancer cell lines but has not been studied in pancreatic cancer. We hypothesized that apigenin would inhibit pancreatic cancer cell growth in vitro.
\end{abstract}

Results: Apigenin caused both time- and concentration-dependent inhibition of DNA synthesis and cell proliferation in four pancreatic cancer cell lines. Apigenin induced G2/M phase cell cycle arrest. Apigenin reduced levels of cyclin A, cyclin B, phosphorylated forms of cdc2 and cdc25, which are all proteins required for $\mathrm{G} 2 / \mathrm{M}$ transition.

Conclusion: Apigenin inhibits growth of pancreatic cancer cells through suppression of cyclin Bassociated cdc2 activity and G2/M arrest, and may be a valuable drug for the treatment or prevention of pancreatic cancer.

\section{Background}

Despite attempts of resection and adjuvant therapy, patients diagnosed with pancreatic cancer continue to have a poor prognosis. Many chemotherapeutic agents have been used to treat pancreatic cancer without particular success. Novel treatments to inhibit cancer cell proliferation with less toxicity are needed. Flavonoids are a class of polyphenolic compounds which display a variety of biologic activities. There has been recent interest in using flavonoid derivatives therapeutically as anticancer drugs. At pharmacological levels, various naturally occurring flavonoids have been shown to be cancer-protective in a variety of animal models. Flavonoid derivatives, such as flavopiridol and genistein, have been shown to be safe in human trials[1,2] and are being assessed as chemotherapy drugs in phase II clinical trials for advanced solid tumors $[3,4]$. 
Flavonoids have shown antitumor activity for a number of cancer cell types $[5,6]$. This is mediated by different types of cell cycle arrest and the induction of apoptosis in several tumor cell lines [7-12]. Genistein, a naturally occurring isoflavone, has shown antitumor activity in pancreatic cancer models [13]. Apigenin, an isoconformer of genistein, has shown more potent growth inhibition in several cancer cell lines [6]. Apigenin has been shown to possess anti-inflammatory effects, free radical scavenging properties, and anti-carcinogenic effects [14]. It has been shown to possess growth inhibitory properties in several cancer lines, including breast, colon, skin, thyroid, and leukemia cells [15-19], but has never been studied in pancreatic cancer. We hypothesized that apigenin would inhibit pancreatic cancer cell growth in vitro, and further aimed to delineate the mechanism involved.

\section{Results}

Apigenin inhibited DNA synthesis

Apigenin caused a concentration-dependent (6.25-100 $\mu \mathrm{M}$ ) inhibition of thymidine incorporation in all four cell lines studied (Figure 1). At 24 hours, $100 \mu \mathrm{M}$ apigenin caused an approximately 50\% inhibition of thymidine incorporation in each cell line. The inhibition of proliferation was statistically significant $(\mathrm{P}<0.01)$ at $100 \mu \mathrm{M}$ apigenin in all cell lines.
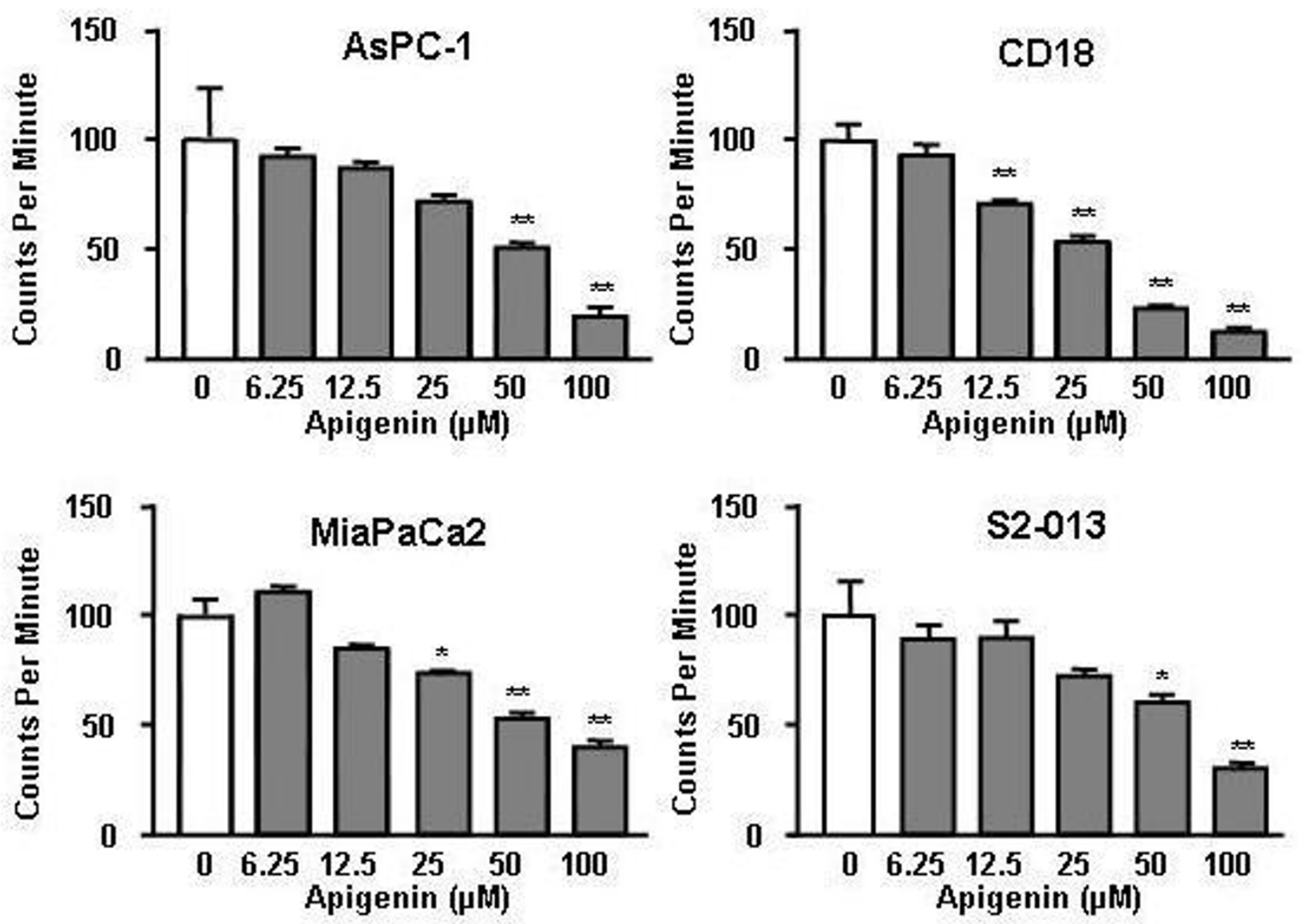

Figure I

Effects of apigenin on DNA synthesis in human pancreatic cancer cells. Apigenin caused significant concentrationdependent inhibition of DNA synthesis in all four cell lines studied: AsPC-I $[F(5,42)=10.12, P<0.000 I ; P=0.01$ with $50-100$ $\mu \mathrm{M}]$; $C D I 8[F(5,54)=38.47, \mathrm{P}<0.000 \mathrm{I} ; \mathrm{P}<0.0 \mathrm{I}$ with I2.5-100 $\mu \mathrm{M}]$; MIA PaCa2 $[F(5,72)=8.698, \mathrm{P}<0.000 \mathrm{I} ; \mathrm{P}<0.05$ with $25 \mu \mathrm{M}$ and $\mathrm{P}<0.0 \mathrm{I}$ with $50-100 \mu \mathrm{M}] ;$ S2-0I $3[F(5,72)=4.099, \mathrm{P}<0.0025 ; \mathrm{P}<0.05$ with $50 \mu \mathrm{M}$ and $\mathrm{P}<0.0 \mathrm{I}$ with $\mathrm{I} 00 \mu \mathrm{M}]$. Data represent results from at least three separate experiments each performed in triplicate, expressed as a percentage of control. 


\section{Apigenin inhibited cell proliferation}

The inhibition of DNA synthesis correlated with a decrease in cell number over a 72-hour period when compared with control. The cell number in untreated cells increased every 24 hours in almost every cell line while cell number of apigenin-treated cells increased at a slower rate, or decreased (Figure 2). The differences in cell number were statistically significant $(\mathrm{P}<0.05)$ at 72 hours in all four cell lines. During the first 24 hours, no significant difference was seen between cells treated with apigenin and controls. Only viable cells were counted so that cytotoxicity did not play a role.
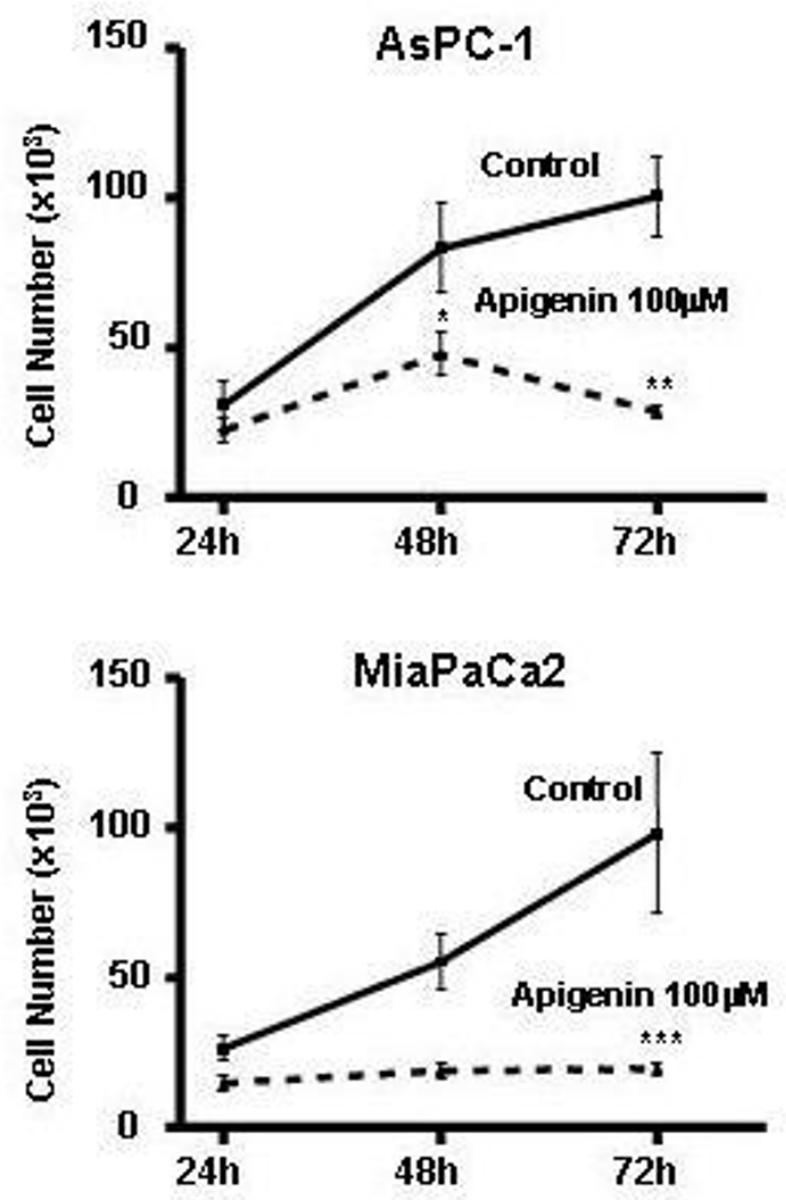

\section{Apigenin induced G2IM phase cell cycle arrest}

In order to better understand the mechanism of inhibition of cell proliferation, the distribution of cells in the different phases of the cell cycle was analyzed following treatment with $100 \mu \mathrm{M}$ apigenin for 24 hours. There were marked and consistent changes in the cell cycle at 24 hours. The number of cells in the G2/M phase increased in all four cell lines with a concomitant decrease in treated cells in the G0/G1 and S phase. The difference between the mean percentage of control and treated cells in the G2/M phase of four separate experiments was statistically significant in all four cell lines (AsPC1: P < 0.01, CD18: P $<0.009$, MiaPaCa2: $\mathrm{P}<0.04$; S2013: $\mathrm{P}<0.03)$. Figure 3 shows the results of one experiment representative of all cell cycle experiments. The concentration-dependent
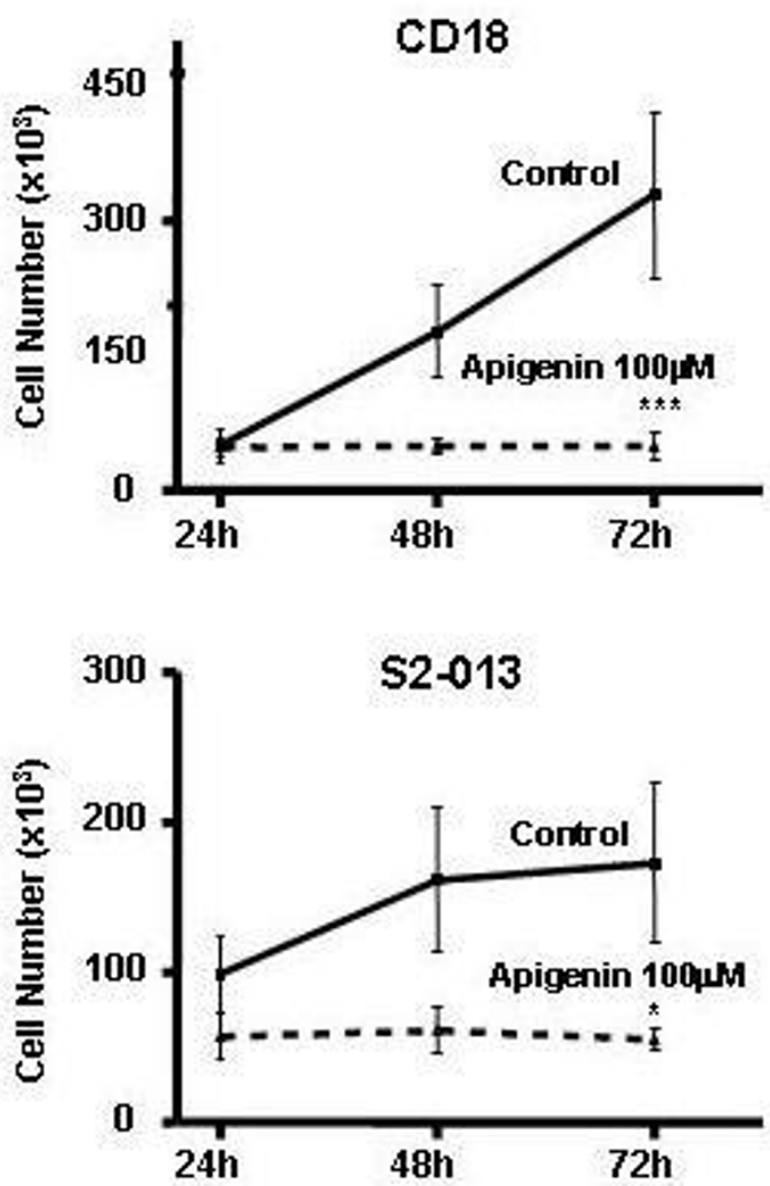

Figure 2

Time-course effects of apigenin on cell number of human pancreatic cells. Apigenin significantly inhibited the increase in cell number of each cell line over time: AsPC-I, $[F(5,59)=10.65, P<0.000 \mathrm{I}], \mathrm{P}<0.05$ at $48 \mathrm{~h}$ and $\mathrm{P}<0.00 \mathrm{I}$ at 72 $\mathrm{h} ; \mathrm{CDI},[F(5,38)=5.64 \mathrm{I}, \mathrm{P}<0.0006], \mathrm{P}<0.00 \mathrm{I}$ at $72 \mathrm{~h} ; \mathrm{MIA} \mathrm{PaCa2},[F(5,65)=6.127, \mathrm{P}<0.000 \mathrm{I}], \mathrm{P}<0.00 \mathrm{I}$ at $72 \mathrm{~h} ; \mathrm{S} 2-0 \mathrm{I} 3$, $[F(5,60)=2.589, P<0.0347], P<0.05$ at $72 \mathrm{~h}$. Data represent results from at least three separate experiments each performed in triplicate, expressed as cell number/well. $*=\mathrm{P}<0.05$; $* *=\mathrm{P}<0.0 \mathrm{I} ; * * *=\mathrm{P}<0.00 \mathrm{I}$ compared with control. 
effects of apigenin on the proportion of cells in the G2/M phase of the cell cycle are shown in Figure 4.

\section{Apigenin changed expression of proteins involved in the G2IM phase transition}

All four pancreatic cancer cell lines were treated with 100 $\mu \mathrm{M}$ apigenin for 24 hours and expression and phosphorylation of proteins involved in the G2/M transition were observed through western blotting (Figure 5). Expression of cyclin A and B was decreased in apigenin treated cells when compared to controls. While expression of cdc2 was unchanged, the levels of phosphorylated cdc2 were decreased in apigenin treated cells. Expression of cdc25A and cdc25C were also decreased in apigenin treated cells compared to controls.

\section{Discussion}

Several mechanisms have been proposed for apigenin's effect on cell growth including modulation of the MAP kinase pathway $[20,21]$, inhibition of ornithine decarboxylase [22], improvement in cell-cell communication through increased gap junctions [23], and cell cycle arrest. Cell-cycle checkpoints at G2/M as well as G1/S are critical in maintaining DNA integrity and regulating the passage of cells through the cell cycle. It is well known that loss of these checkpoints is involved in the transformation into and progression of cancer cells. A protein kinase complex consisting of a catalytic subunit, cdc2, and the cyclin B protein performs the central and rate-limiting function in the transition from G2 to M phase [24]. The cdc2/cyclin B complex responds to DNA damage and causes a delay in cell cycle progression to allow DNA repair before cells
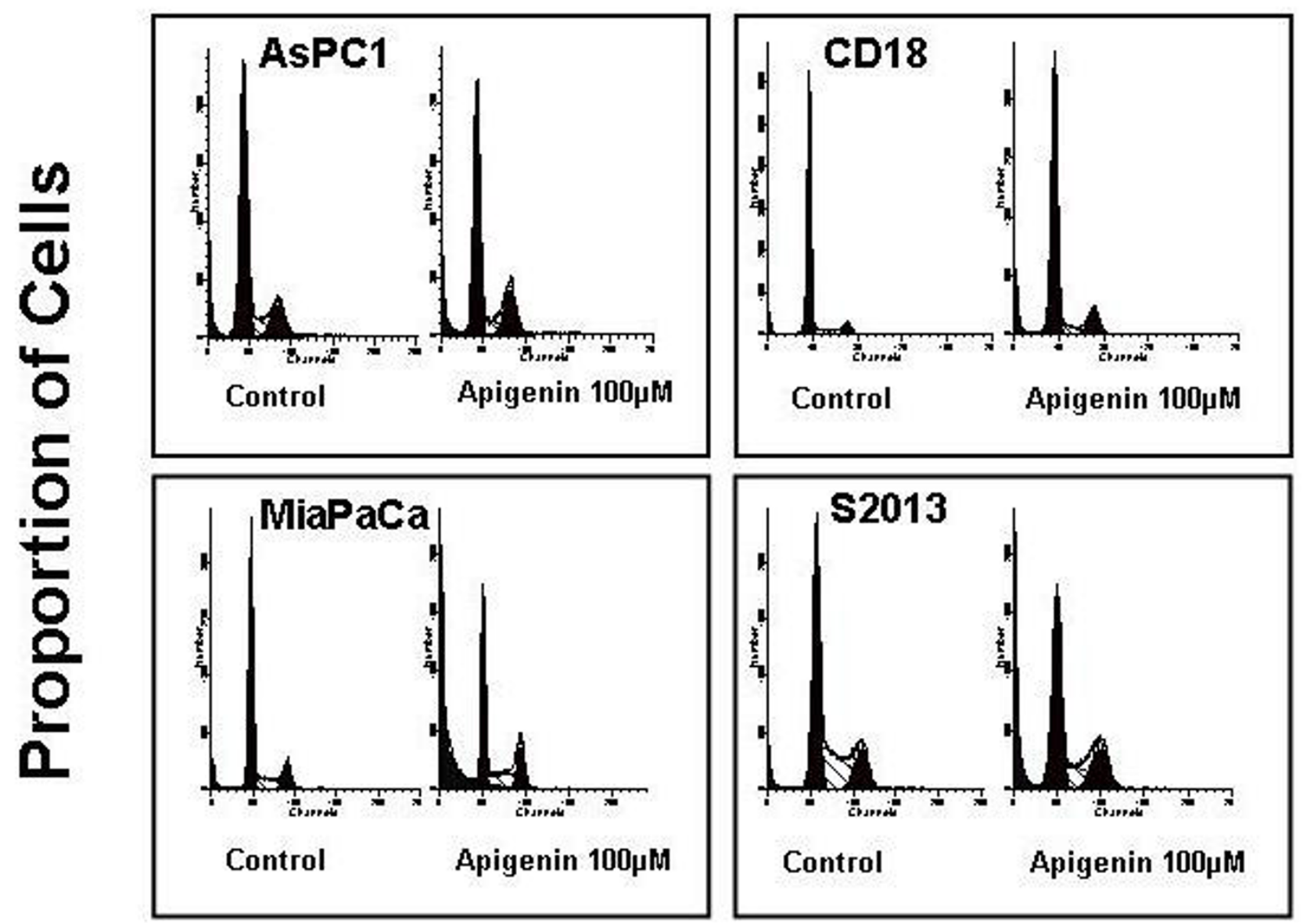

\section{DNA Content}

Figure 3

Effects of apigenin on the proportion of cells in different phases of the cell cycle. Apigenin caused G2/M arrest in all four human pancreatic cancer cell lines studied. Similar results were seen in four different experiments. 

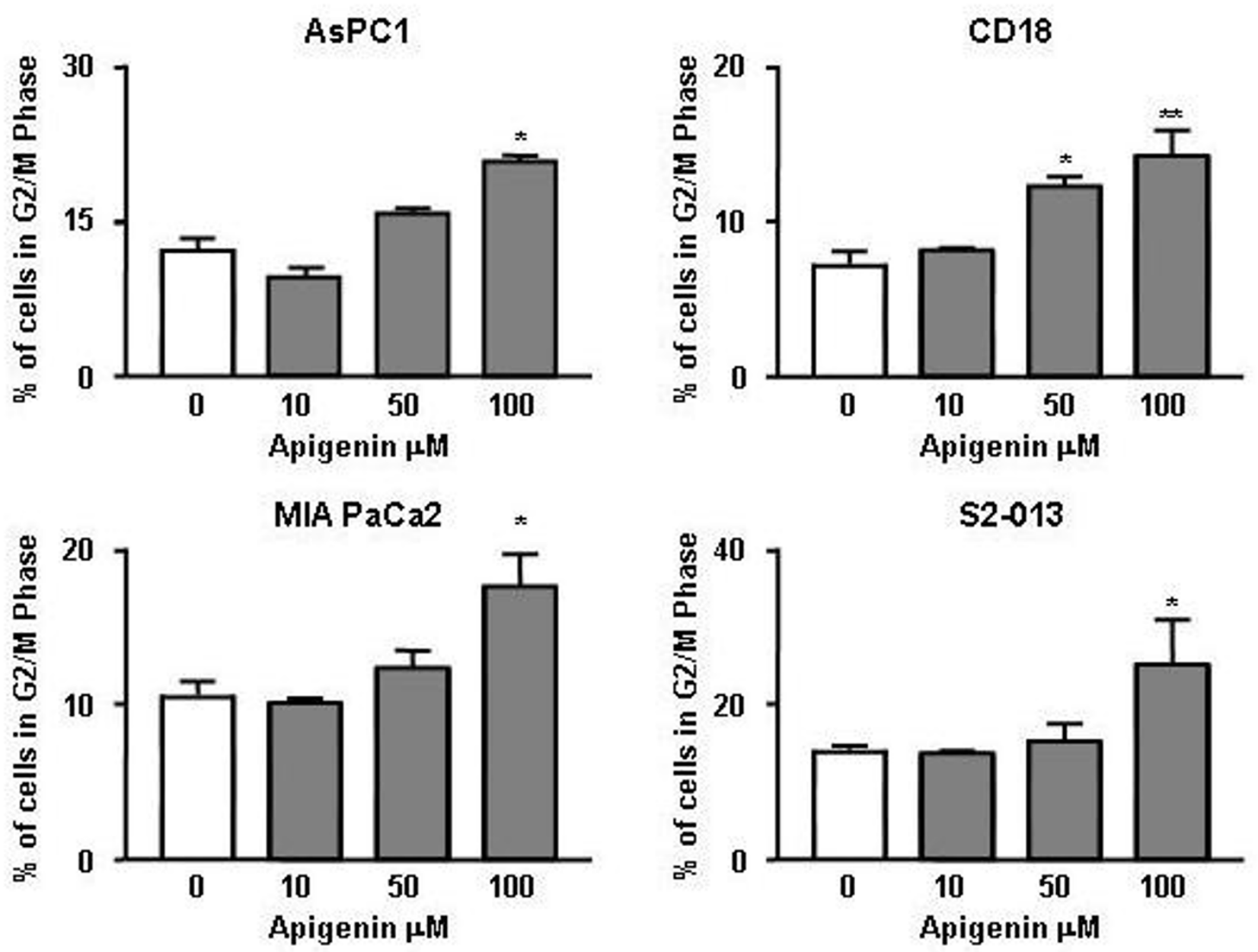

Figure 4

Concentration-dependent effects of apigenin on the cell cycle. Higher concentrations of apigenin cause a concomitant increase in the percentage of cells in the G2/M phase. AsPC-I $[F(3,8)=12.79, P<0.002(P<0.01$ with I00 $\mu M)]$; CDI8 $[F$ $(3,8)=9.504, \mathrm{P}<0.0128(\mathrm{P}<0.05$ with $50 \mu \mathrm{M}$ and $\mathrm{P}<0.01$ with $100 \mu \mathrm{M})] ; \mathrm{MIA} \mathrm{PaCa} 2[F(3, I 0)=6.062, \mathrm{P}<0.0128(\mathrm{P}<0.0 \mathrm{I}$ with $100 \mu \mathrm{M})]$; S2-0I $3[F(3, I 0)=4.07 \mathrm{I}, \mathrm{P}<0.0394(\mathrm{P}<0.05$ with $100 \mu \mathrm{M})]$. $*=\mathrm{P}<0.05$; $* *=\mathrm{P}<0.0 \mathrm{I}$ compared with control.

enter mitosis. The complex accomplishes this through phosphorylation of cytoskeleton proteins such as lamins and histone H1 [25]. Cdc2 binding to cyclin B in and of itself is not enough, however, for checkpoint progression. Dephosphorylation of cdc2 at the Tyr-15 site through cdc25c phosphatase is required for activation of the complex $[24,26]$. Cdc25A also contributes to the cellular phosphatase pool required to dephosphorylate cdc2 fully [27]. Cyclin A, known mainly for its role in G1/S transition, is also required for the entry of cells into mitosis [28,29].

In the current study, treatment of human pancreatic cancer cells with apigenin resulted in inhibition of DNA synthesis and cell proliferation through G2/M cell cycle arrest. A decrease in levels of cyclin A, cyclin B, cdc25 A and cdc25C all appear to be involved. It is not clear why levels of phosphorylated cdc2 were decreased given that reduced levels of cdc25c should have the opposite effect, however, the reduced levels of cyclin $\mathrm{B}$ appear to be the main mechanism involved in the arrest of cells at G2/M.

Our results are congruent with previous studies in which cell cycle arrest has been shown to result from apigenin treatment in other cell lines. G2/M arrest through inhibition of cyclin B associated cdc2 has been shown to occur in epidermal and fibroblast cells $[8,30]$, breast cancer cells [31], oral cancer cells [32], melanoma [33], mouse keratinocytes [34], endothelial cells [35], prostate cancer cells [36], and colon cancer cell lines [16]. Interestingly, inhibition of cyclin B appears to be concentration-related as lower doses have less effect while higher doses $(>70 \mu \mathrm{M})$ as we used in our study decrease cyclin B levels [34]. 


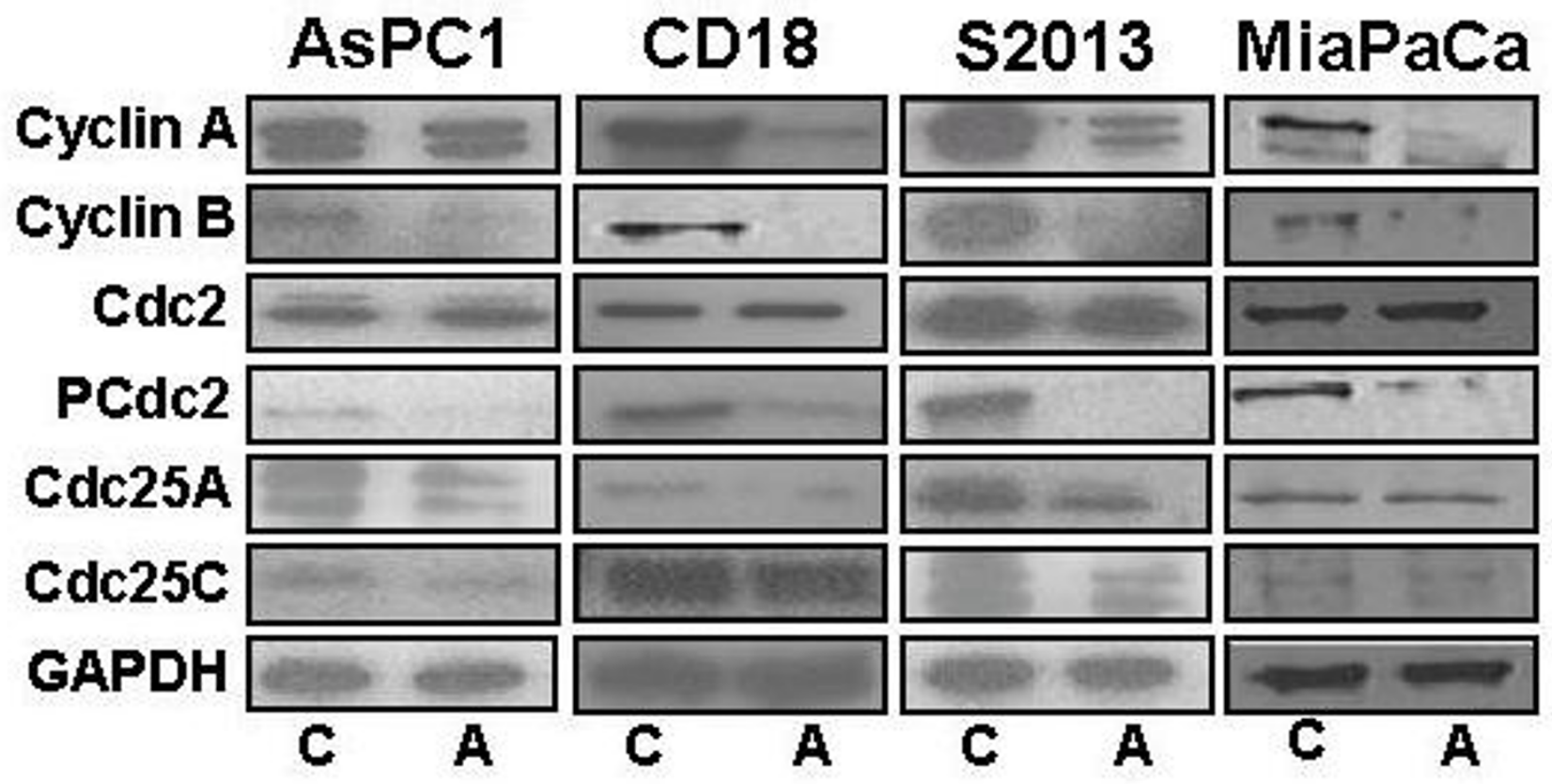

Figure 5

Effects of apigenin on proteins involved in the G2/M cell cycle phase transition. Expression of both cyclin A and cyclin $B$ were both decreased in apigenin-treated cells compared to controls. While the expression of the cdc 2 protein was unchanged, levels of phosphorylated cdc2 were decreased in treated cells. Expression of cdc25A and cdc $25 \mathrm{C}$ were also decreased in treated cells compared to controls.

A considerable amount of attention has been given to the role of p53 in cell cycle checkpoint control. P53 blocks cells at G2/M through direct inhibition of cdc2 kinase [37]. All four cell lines used in this study contain mutated p53, which implies that the G2/M arrest seen after apigenin treatment is through a p53-independent pathway. Other studies have found this to be the case as well. Apigenin was found to inhibit growth in both p53 wild-type and mutated breast cancer cells [15], p53 mutated oral squamous cell cancer cells [32], and mutated colon cancer cell lines [16].

\section{Conclusion}

To our knowledge there is no published data concerning apigenin in pancreatic cancer. Our results demonstrate that apigenin inhibits human pancreatic cancer cell growth in vitro through G2/M phase cell cycle arrest associated with decreased cyclin B-cdc2 activity. Taken together with previously published studies, apigenin appears to exert its inhibitory effects on cell cycle progression in other cell lines as well. Cancer cells with abnormal cell-cycle machinery may benefit from extrinsic cell-cycle regulators such as apigenin.

\section{Methods}

Materials

DMEM, trypsin-EDTA solution, and propidium iodide were purchased from Sigma (St. Louis, MO). Fetal bovine serum was purchased from Atlanta Biologicals (Norcross, GA). Apigenin was purchased from Calbiochem (Darmstadt, Germany) and dissolved in DMSO purchased from Sigma Chemicals (St. Louis, MO). Methyl ${ }^{3} \mathrm{H}$-Thymidine was purchased from Amersham (Arlington Heights, IL). The monoclonal mouse cyclin A, B, cdc25A, and GAPDH antibodies, and the polyclonal rabbit cdc25C antibody were purchased from Santa Cruz Biotechnology (Santa Cruz, CA). The monoclonal rabbit cdc2 and phosphocdc2 (Tyr ${ }^{15}$ ) antibodies were purchased from Cell Signaling Technology, Inc. (Beverly, MA).

\section{Human pancreatic cancer cell lines and cell culture}

We selected four human pancreatic cancer cell lines: AsPC-1, CD18, MIA PaCa2, and S2-013. These cell lines were purchased from American Type Culture Collection (Manassas, VA) with the exception of the S2-013 cell line, which was a generous gift from Dr. Takeshi Iwamura (Japan). Each cell line was grown in DMEM and plated as 
monolayers in medium supplemented with $10 \%$ fetal bovine serum in a humidified atmosphere of $95 \% \mathrm{O}_{2}$ and $5 \% \mathrm{CO}_{2}$ at $37^{\circ} \mathrm{C}$. The cells were regularly seeded into $75-$ $\mathrm{cm}^{2}$ flasks with media changes every second or third day. For experiments, cells were grown to $70 \%$ confluence, digested with trypsin-EDTA, and plated in 6-, 24-, or 48well plates.

\section{DNA synthesis by methyl-3 $\boldsymbol{H}$ thymidine incorporation}

Cells were plated in 24-well plates at a concentration of 50,000 cells/well. After reaching 50\% confluence, they were incubated in serum-free medium for 24 hours, which was then replaced with fresh serum-free medium with or without the appropriate treatments. After the required period of culture, cellular DNA synthesis was assayed by adding $0.5 \mu \mathrm{Ci}$ methyl ${ }^{3} \mathrm{H}$-thymidine/well and incubating cells for another 6 hours. The cells were then washed twice with PBS, fixed with 10\% trichloroacetic acid, and solubilized by adding $250 \mu \mathrm{l}$ of $0.4 \mathrm{M} \mathrm{NaOH}$ to each well. Radioactivity, indicating incorporation of methyl ${ }^{3} \mathrm{H}$-thymidine into DNA, was measured by adding scintillation cocktail and counting on a scintillation counter (LKB RackBeta; Wallac, Turku, Finland).

\section{Cell proliferation assay}

Cells were regularly seeded into three 6 -well plates and incubated at $37^{\circ} \mathrm{C}$ for 24 hours. Cells were then cultured in serum-free medium for another 24 hours and treated in fresh serum-free medium with or without apigenin for 24, 48 , and 72 hours. At the end of each time period, the cells were trypsinized to produce a single cell suspension, and the viable cell number in each well was counted using Guava Technologies' ViaCount Assay (Guava Technologies Inc, Hayward, CA).

\section{Analysis of cellular DNA content by flow cytometry}

Cells were grown to $50 \%$ confluence in $\mathrm{T} 75-\mathrm{cm}^{2}$ flasks, serum starved for 24 hours, and then treated with apigenin. At the end of the treatment, the cells were harvested with trypsin-EDTA solution to produce a single-cell suspension. Cells were then pelleted by centrifugation and washed twice with PBS. The cell pellets were then suspended in $0.5 \mathrm{~mL}$ PBS and fixed in ice-cold 70\% ethanol at $4^{\circ} \mathrm{C}$. The fixed cells were then centrifuged at $\times 300 \mathrm{~g}$ for 10 minutes and pellets washed with PBS. After resuspension in $1 \mathrm{ml}$ PBS, the cells were incubated with $10 \mu \mathrm{L}$ Rnase I $(10 \mathrm{mg} / \mathrm{ml})$ and $100 \mu \mathrm{L}$ propidium iodide $(400 \mathrm{~g} /$ $\mathrm{mL}$ ) and shaken for 1 hour at $37^{\circ} \mathrm{C}$ in the dark. The samples were then analyzed by flow cytometry.

\section{Western blotting}

Cells were seeded in T25-cm² flasks and grown to $60 \%$ confluence for 24 hours. The cells were serum starved for 24 hours. The cells were then placed in serum-free medium with or without $100 \mu \mathrm{M}$ apigenin for 24 hours.
The cells were lysed and protein concentrations determined with BSA as standard. Equal amounts of cell protein lysate were separated on 15\% SDS-polyacrylamide gel electrophoresis (PAGE) and the protein transferred onto nitrocellulose membranes. After blocking with dried milk, membranes were incubated with the appropriate dilution of primary antibody. Membranes were then incubated with a horseradish peroxidase-conjugated secondary antibody. Proteins were detected using the enhanced chemiluminescence detection system.

\section{Statistical analysis}

Data were analyzed by ANOVA with Dunnett's or Bonferoni's corrections for multiple comparisons, as appropriate. This analysis was performed with the Prism software package (GraphPad, San Diego, CA). Data were expressed as mean \pm SEM.

\section{Authors' contributions}

MU carried out the cell culture work, thymidine incorporation, cell proliferation assays, flow cytometry, statistical analyses, and wrote the manuscript. XD participated in the conception of the study, its design and coordination, and helped draft the manuscript. MS carried out the western blotting. LG assisted with cell proliferation assays and western blotting. BM assisted with cell proliferation assays and western blotting. DB helped draft and prepare the manuscript. MT and RB participated in the design and coordination of the study. TA participated in the conception and design of the study, participated in the statistical analysis, participated in the coordination of the study and edited the manuscript.

\section{References}

I. Shah MA, Kortmansky J, Motwani I, Drobnjak M, Gonen M, Yi S, Weyerbacher A, Cordon-Cardo C, Lefkowitz R, Brenner B, O'Reilly E, Saltz L, Tong W, Kelsen DP, Schwartz GK: A phase I clinical trial of sequential combination of irinotecan followed by flavopiridol. Clin Cancer Res 2005, I I:3836-3845.

2. Whitlock JA, Krailo M, Reid JM, Ruben SL, Ames MM, Owen W, Reaman G: Phase I clinical and pharmacokinetic study of flavopiridol in children with refractory solid tumors: a Children's Oncology Group Study. J Clin Oncol 2005, 23:9179-9186.

3. deVere White RW, Hackman RM, Soares SE, Beckett LA, Li Y, Sun B: Effects of a genistein-rich extract on PSA levels in men with a history of prostate cancer. Urology 2004, 63:259-263.

4. Kelland LR: Flavopiridol, the first cyclin-dependent kinase inhibitor to enter the clinic: current status. Expert Opin Investig Drugs 2000, 9:2903-29II.

5. Fotsis T, Pepper MS, Aktas E, Breit S, Rasku S, Adlercreutz H, Wahala $\mathrm{K}$, Montesano R, Schweigerer L: Flavonoids, dietary-derived inhibitors of cell proliferation and in vitro angiogenesis. Cancer Res 1997, 57:2916-2921.

6. Li Y, Ahmed F, Ali S, Philip PA, Kucuk O, Sarkar FH: Inactivation of nuclear factor kappaB by soy isoflavone genistein contributes to increased apoptosis induced by chemotherapeutic agents in human cancer cells. Cancer Res 2005, 65:6934-6942.

7. Gupta S, Afaq F, Mukhtar H: Involvement of nuclear factorkappa B, bax and bcl-2 in induction of cell cycle arrest and apoptosis by apigenin in human prostate carcinoma cells. Oncogene 2002, 21:3727-3738. 
8. Lepley DM, Li B, Birt DF, Pelling JC: The chemopreventive flavonoid apigenin induces $\mathbf{G} 2 / \mathrm{M}$ arrest in keratinocytes. Carcinogenesis 1996, 17:2367-2375.

9. Losiewicz MD, Carlson BA, Kaur G, Sausville EA, Worland PJ: Potent inhibition of cdc2 kinase activity by the flavonoid L86-8275. Biochem Biophys Res Commun 1994, 201:589-595.

10. Kobayashi T, Nakata T, Kuzumaki T: Effect of flavonoids on cell cycle progression in prostate cancer cells. Cancer Lett 2002, 176: 17-23.

II. Wang $\mathrm{H}$ : The therapeutic potential of flavonoids. Expert Opin Investig Drugs 2000, 9:2103-2119.

12. Birt D, Hendrich S, Wang W: Dietary agents in cancer prevention: flavonoids and isoflavonoids. Pharmacol Ther 200I, 90:157-177.

13. Buchler P, Reber HA, Buchler MW, Friess H, Lavey RS, Hines O]: Antiangiogenic activity of genistein in pancreatic carcinoma cells is mediated by the inhibition of hypoxia-inducible factor-I and the down-regulation of VEGF gene expression. Cancer 2004, 100:201-210.

14. Kim HP, Mani I, Iversen L, Ziboh VA: Effects of naturally-occurring flavonoids and bioflavonoids on epidermal cyclooxygenase and lipoxygenase from guinea-pigs. Prostaglandins Leukot Essent Fatty Acids 1998, 58: 17-24.

15. Yin F, Giuliano AE, Law RE, Van Herle AJ: Apigenin inhibits growth and induces $\mathrm{G} 2 / \mathrm{M}$ arrest by modulating cyclin-cdk regulators and ERK MAP kinase activation in breast carcinoma cells. Anticancer Res 200I, 21:413-420.

16. Wang W, Heideman L, Chung CS, Pelling JC, Koehler KJ, Birt DF Cell-cycle arrest at $\mathbf{G 2} / \mathrm{M}$ and growth inhibition by apigenin in human colon carcinoma cell lines. Mol Carcinog 2000, 28:102-110.

17. Caltagirone S, Rossi C, Poggi A, Ranelletti FO, Natali PG, Brunetti M, Aiello FB, Piantelli M: Flavonoids apigenin and quercetin inhibit melanoma growth and metastatic potential. Int / Cancer 2000 87:595-600

18. Yin F, Giuliano AE, Van Herle AJ: Growth inhibitory effects of flavonoids in human thyroid cancer cell lines. Thyroid 1999 9:369-376

19. Takahashi T, Kobori M, Shinmoto H, Tsushida T: Structure-activity relationships of flavonoids and the induction of granulocyticor monocytic-differentiation in HL60 human myeloid leukemia cells. Biosci Biotechnol Biochem 1998, 62:2199-2204.

20. Kuo ML, Yang NC: Reversion of v-H-ras-transformed NIH 3T3 cells by apigenin through inhibiting mitogen activated protein kinase and its downstream oncogenes. Biochem Biophys Res Commun 1995, 21 2:767-775.

21. Van Dross R, Xue $Y$, Knudson A, Pelling JC: The chemopreventive bioflavonoid apigenin modulates signal transduction pathways in keratinocyte and colon carcinoma cell lines. J Nutr 2003:3800-3804.

22. Wei H, Tye L, Bresnick E, Birt DF: Inhibitory effect of apigenin, a plant flavonoid, on epidermal ornithine decarboxylase and skin tumor promotion in mice. Cancer Res 1990, 50:499-502.

23. Chaumontet C, Droumaguet C, Bex V, Heberden C, Gaillard-Sanchez I, Martel P: Flavonoids (apigenin, tangeretin) counteract tumor promoter-induced inhibition of intercellular communication of rat liver epithelial cells. Cancer Lett 1997, I | 4:207-210.

24. Norbury C, Nurse P: Animal cell cycles and their control. Annu Rev Biochem 1992, 61:441-470.

25. Johnson DG, Walker CL: Cyclins and cell cycle checkpoints. Annu Rev Parmacol Toxicol 1999, 39:295-3। 2.

26. Sampath $D$, Plunkett W: Design of new anticancer therapies targeting cell cycle checkpoint pathways. Curr Opin Oncol 200I, 13:484-490.

27. Mailand N, Podtelejnikov AV, Groth A, Mann M, Bartek J, Lukas J: Regulation of G2/M events by cdc25A through phosphorylation-dependent modulation of its stability. EMBO J 2002, 21:59||-5920

28. Furuno N, Den Elzen N, Pines J: Human cyclin $\mathbf{A}$ is required for mitosis until mid prophase. J Cell Biol 1999, 147:95-306.

29. Pagano M, Pepperkok R, Verde F, Angorge W, Draetta G: Cyclin A is required at two points in the human cell cycle. EMBOJ 1992, II:961-97I.
30. Lepley DM, Pelling JC: Induction of p2 I/WAFI and G I cell-cycle arrest by the chemopreventive agent apigenin. Mol Carcinog 1997, 19:74-82.

31. Lindenmeyer F, Li H, Menashi S, Soria C, Lu H: Apigenin acts on the tumor cell invasion process and regulates protease production. Nutr Cancer 200I, 39:139-147.

32. O'Prey J, Brown J, Fleming J, Harrison PR: Effects of dietary flavonoids on major signal transduction pathways in human epithelial cells. Biochem Pharmacol 2003, 66:2075-2088.

33. Casagrande F, Darbon JM: Effects of structurally related flavonoids on cell cycle progression of human melanoma cells: regulation of cyclin-dependent kinases CDK2 and CDK1. Biochem Pharmacol 200I, 6 I:I205-1215.

34. McVean M, Weinberg WC, Pelling JC: A p2 I WAFI-independent pathway for inhibitory phosphorylation of cyclin-dependent kinase p34cdc2 and concomitant G2/M arrest by the chemopreventive flavonoid apigenin. Mol Carcinog 2002, 33:36-43.

35. Trochon V, Blot E, Cymbalista F, Engelman C, Tang R, Thomaidis A Vasse M, Soria J, Lu H, Soria C: Apigenin inhibits endothelial-cell proliferation in G2/M phase whereas it stimulates smoothmuscle cells by inhibiting p2I and p27 expression. Int J Cancer 2000, 85:69l-696.

36. Gupta S, Afaq F, Mukhtar H: Selective growth-inhibitory, cellcycle deregulatory and apoptotic response of apigenin in normal versus human prostate carcinoma cells. Biochem Res Commun 200I, 287:914-920.

37. Taylor WR, Stark GR: Regulation of the G2/M transition by $\mathbf{p 5 3}$. Oncogene 200I, 20:1803-18I5.
Publish with Biomed Central and every scientist can read your work free of charge

"BioMed Central will be the most significant development for disseminating the results of biomedical research in our lifetime. "

Sir Paul Nurse, Cancer Research UK

Your research papers will be:

- available free of charge to the entire biomedical community

- peer reviewed and published immediately upon acceptance

- cited in PubMed and archived on PubMed Central

- yours - you keep the copyright 